\title{
Comparative Study of Leaching of Aluminium from Aluminium, Clay, Stainless Steel, and Steel Cooking Pots
}

\author{
A. T. Odularu, ${ }^{1}$ P. A. Ajibade, ${ }^{1}$ and P. C. Onianwa ${ }^{2}$ \\ ${ }^{1}$ Department of Chemistry, University of Fort Hare, Alice 5700, South Africa \\ ${ }^{2}$ Department of Chemistry, University of Ibadan, Ibadan, Nigeria
}

Correspondence should be addressed to P. A. Ajibade; pajibade@ufh.ac.za

Received 17 June 2013; Accepted 22 July 2013

Academic Editors: A. R. Mawson and B. Polivka

Copyright (c) 2013 A. T. Odularu et al. This is an open access article distributed under the Creative Commons Attribution License, which permits unrestricted use, distribution, and reproduction in any medium, provided the original work is properly cited.

\begin{abstract}
Analyses on the absorption of aluminium by rice boiled in distilled water in a variety of containers, such as old and new aluminium pots, clay receptacles, stainless steel pots, and steel pots, were carried out. $10 \mathrm{~g}$ of rice was taken as a representative sample. Colorimetric analysis of classical methods was used to determine the concentration of aluminium. The control for aluminium was $350 \pm 130 \mu \mathrm{g} / \mathrm{g}$. The new aluminium pots had a concentration of $126 \pm 64 \mu \mathrm{g} / \mathrm{g}$, old aluminium pots had $314 \pm 128 \mu \mathrm{g} / \mathrm{g}$, new clay pots had $132 \pm 68 \mu \mathrm{g} / \mathrm{g}$, old clay pots had $195 \pm 137 \mu \mathrm{g} / \mathrm{g}$, new steel pots had $241.00 \pm 200 \mu \mathrm{g} / \mathrm{g}$, old steel utensils had $186.83 \pm$ $75.18 \mu \mathrm{g} / \mathrm{g}$, new stainless steel utensils had $294.83 \pm 163 \mu \mathrm{g} / \mathrm{g}$, and old stainless steel utensils had $289.00 \pm 75.155 \mu \mathrm{g} / \mathrm{g}$. Aluminium leaching was detected in all forms of new and old cooking utensils, and leaching was below and within the control concentration range. Old aluminium pots had the highest concentration of leaching while new steel pots had the least leaching of aluminium. However, the aluminium contamination of the foods tested was insufficient to constitute a hazard to health.
\end{abstract}

\section{Introduction}

Aluminium is the third most abundant element in the earth's crust more than other elements [1-3]. From both health and medical points of view, oral ingestion of moderate doses of aluminum in healthy subjects has not been associated with any particular disease $[4,5]$. With the possible exception of aluminum phosphate studies, aluminum appears to be associated with the brain lesion characteristics of Alzheimer's diseases, associated with aluminum in drinking water in several epidemiological studies [4-10]. The concentration of aluminium was confirmed in the brain tissue of a patient with Alzheimer's disease, Parkinson's disease, and encephalopathy [8-11]. An average of $30 \mathrm{mg}$ of aluminium is consumed through water, food, and drugs daily $[8,11]$. Before 1980, the daily intake of aluminium was reported to be $18-36 \mathrm{mg}$ per day. According to recent data from the World Health Organization (WHO), the following was reported: a daily consumption of $9 \mathrm{mg}$ of aluminium for teenage and adult females while for teenage and adult males a daily consumption of 12$14 \mathrm{mg}$ of aluminium. In 1989, WHO reported that provisional tolerance weekly intake (PTWI) is $7 \mathrm{mg}$ of aluminium per kilogram per body weight $[9,11-14]$.

Therefore, for a person with a weight of $60 \mathrm{~kg}$, the acceptable dosage is not more than $60 \mathrm{mg} /$ day.

Some researchers reported the concern of the absorption of aluminium from cookwares, such as acidic food like tomatoes and basic foods like cereals and oils corrode aluminium alloys [1,13-16].

Aluminum is used in the manufacture of domestic cooking utensils, because it can be bent or pressed into various shapes. The conductivity for heat is useful in cooking vessels. Its ductility results in aluminium wire, used as a reducing agent in the "Thermite Process" to produce molten iron for welding purposes, its malleability to make silver paper for milk bottle caps and food wrappings, as well as, alloys because of its high tensile strength and light weight. Aluminum cookware, apart from other sources of dietary aluminum, is considered to be a potential source of aluminum leaching experiments with food, beverages, water under different experimental conditions modified by varying the levels of $\mathrm{pH}$, chlorides, fluorides, citrate, and acetate [13-16]. The result 
reported by different workers showed marked discrepancies in levels of leached out aluminum, which can be attributed to factors such as non-symmetrical, nonuniform, and nonstandard experimental designs [13-16].

1.1. Aim of the Research. The aim of this research is to determine the rate at which aluminium ions leached out from both old and new cooking pots.

\section{Experimental Analysis}

2.1. Materials. Raw rice, old and new pots of aluminium, clay, steel and stainless steel, electric cookers, stop-watch, and distilled water.

In this work, raw rice was chosen as a staple food in the local environment of the western part of Nigeria. A certain brand of rice was sampled from a lot of its kind from a typical market in the southwest region of Nigeria. The final sample was sampled by quartering or coning. The rice was winnowed to remove dirt.

New pots of aluminium, clay, stainless steel, and steel were only rinsed with water to remove dirt because of their newness before using them.

The old pots ( $2-5$ years) of these pots, whose history was unknown, were washed with detergent and sponge and later rinsed with tap water. Finally, tap water was boiled in all of them for at least an hour for proper cleaning.

\subsection{Methods}

2.2.1. Analysis of Raw Rice for Sample Preparation (Control 1). For sample preparation, the raw rice was ground to powder or finely divided granules in a clean dry wooden mortar and pestle were used. The resulting homogenized, well-mixed samples were placed in an oven at $65-70^{\circ} \mathrm{C}$ to remove moisture.

Ten grams was taken as a representative sample. The raw, ground dried rice was ashed by dry digestion in preweighed porcelain crucibles and later in a muffle furnace at $500-550^{\circ} \mathrm{C}$ for 3-4 hours. This was followed by cooling in a desiccator and subsequently rinsed with $5 \mathrm{~mL}$ of $5 \mathrm{M} \mathrm{HCl}$ to dissolve the ash for aluminum determination. The dissolved ash solutions were steam heated to remove any adhered metal, cooled, and individually filtered through a Whatman filter paper into a $25 \mathrm{~mL}$ standard flask and made up to the mark with distilled water. The extracts were transferred quantitatively into preheated plastic sample bottles, tightly closed, and kept in a refrigerator at a temperature around $4^{\circ} \mathrm{C}$.

2.2.2. Analysis of Cooked Rice for Sample Preparation. All the new, old,and very old pots of stainless steel and steel pots were washed with soapy water, rinsed with tap water and distilled water, and later filled with distilled water to boil on electric cookers/hot plates at the same time. When the water was boiled, the raw unwashed grains were got inside to boil for thirty minutes for proper heating and softness. The pots were individually removed from the electric cookers and the boiled rice, drained in different pretreated colanders. The well-drained rice was each subjected to a constant weight in an oven before grinding and ashing.
2.2.3. Control 2. Raw rice samples were also cooked in $800 \mathrm{~mL}$ beaker as control 2. The boiled rice was dried in an oven at $65-70^{\circ} \mathrm{C}$ and finally removed until a constant weight was obtained and later cooled in a desiccator. The boiled rice was ground in clean earthen mortars. The homogenized samples were dried to constant weight and cooled.

Ten grams was taken as representative sample. The samples were subjected to dry digestion in preheated porcelain crucibles and later in a muffle furnace at $500-550^{\circ} \mathrm{C}$ for 3 4 hours. This was followed by cooling in a desiccator and subsequently digested with $5 \mathrm{~mL}$ of $5 \mathrm{M} \mathrm{HNO}$ prepared solution to dissolve the ash. The dissolved ash solutions were steam heated to remove any adhered metal, cooled, and individually filtered through a Whatman filter paper into a $25 \mathrm{~mL}$ standard flask and made up to the mark with distilled water. The extracts were transferred quantitatively into preheated plastic sample bottles, tightly closed, and kept in a refrigerator at a temperature around $4^{\circ} \mathrm{C}$.

\subsubsection{Raw Rice Samples Underwent Cooking Procedure}

Preparation of Blank Solution. A blank solution was prepared to test for aluminium contamination from the distilled water. A $5 \mathrm{~mL}$ of $5 \mathrm{M} \mathrm{HCl}$ for aluminum was prepared, measured, and then transferred quantitatively into $25 \mathrm{~mL}$ standard flasks and made up to the mark with distilled water.

\subsubsection{Aluminum Analysis by Colorimetry Using Aluminon} Method. The principle of the aluminon method is that aluminon reagent reacts with aluminum in the presence of an ammonium acetate buffer to form a bright red solution.

The intensity of this colour, which is proportional to the aluminum concentration, is obtained by taking the absorbance at $550 \mathrm{~nm}$.

Preparation of Standards for Calibration. The aluminum standard solution was prepared by dissolving $0.42 \mathrm{~g}$ of ammonium alum, $\left(\mathrm{NH}_{4}\right)_{2} \mathrm{SO}_{4} \cdot \mathrm{Al}_{2}\left(\mathrm{SO}_{4}\right)_{3} \cdot 2 \mathrm{H}_{2} \mathrm{O}$ in distilled water containing $10 \mathrm{~mL}$ of concentrated of $25 \mu \mathrm{g} / \mathrm{mL} \mathrm{Al}$ (25 ppm $\mathrm{Al})$. To avoid error in the process, $10 \mathrm{~mL}$ of the aluminum standard solution was pipette and diluted to $100 \mathrm{~mL}$ to give a concentration of $2.5 \mu \mathrm{g} / \mathrm{mL}$ (2.5 ppm Al).

Aluminum Working Solutions. The following volumes of the aluminum working solutions were introduced with pipettes into $50 \mathrm{~mL}$ standard flasks $4.0 \mathrm{~mL}, 8.0 \mathrm{~mL}, 12.0 \mathrm{~mL}, 16.0 \mathrm{~mL}$, $20.0 \mathrm{~mL}$, and $24 \mathrm{~mL}$ - which all corresponded to the following amounts of aluminum: $10 \mu \mathrm{g}, 20 \mu \mathrm{g}, 30 \mu \mathrm{g}, 40 \mu \mathrm{g}, 50 \mu \mathrm{g}$, and $60 \mu \mathrm{g}$, respectively. These aluminum working solutions were transferred to $150 \mathrm{~mL}$ volumetric flasks. To each, $1 \mathrm{~mL}$ of $5 \mathrm{M} \mathrm{HCl}$ was added, to prevent the separation of $\mathrm{Al}(\mathrm{OH})_{3}$, and heated to boiling for 15 minutes to dissolve any aluminum compounds in suspension. This was cooled to $20^{\circ} \mathrm{C}$, and 1 to 2 drops of nitro phenol indicator solution were added. The $\mathrm{pH}$ was adjusted by running in $1.2 \mathrm{M} \mathrm{NH}_{4} \mathrm{OH}$ solution until the solution was just yellow. The colour was discharged by the addition of few drops of dilute $\mathrm{HCl}$. Then $0.5 \mathrm{~mL}$ of thioglycolic acid was added to inhibit the interference due to iron. 
TABLE 1: The concentrations of aluminum in rice samples.

\begin{tabular}{lc}
\hline & $\mathrm{Al}(\mu \mathrm{g} / \mathrm{g})$ \\
\hline New aluminum pot & $126 \pm 64$ \\
Old aluminum pot & $314 \pm 128$ \\
New clay pot & $132 \pm 68$ \\
Old clay pot & $195 \pm 137$ \\
New steel pot & $241 \pm 200$ \\
Old steel pot & $187 \pm 75$ \\
New stainless steel pot & $295 \pm 163$ \\
Old stainless steel pot & $289 \pm 155$ \\
Control & $350 \pm 130$ \\
\hline
\end{tabular}

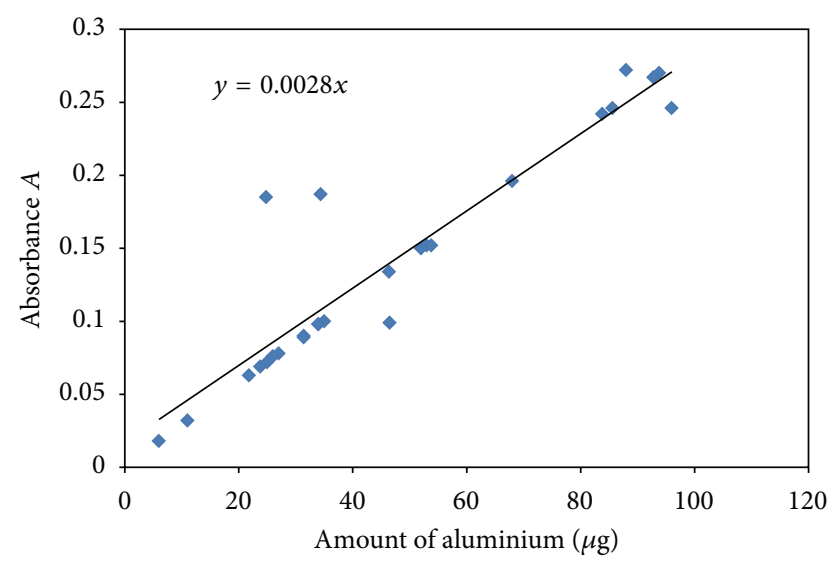

FIgURE 1: Determination of aluminum in the sample.

The calibration graph was prepared using the aluminum standard solutions. The absorbance reading obtained for the blank was subtracted from that obtained for each aluminum standard solution. A graph of absorbance versus amount of aluminum standard solution was plotted, and using the regression correlation factor, the best straight line was drawn through the points. The results are shown in Figure 1 and Table 1 . The diluted sample $(50 \mathrm{~mL})$ sample solution, early prepared, was transferred into a $150 \mathrm{~mL}$ volumetric flask and the procedure as that for the standard solutions was follows, starting from the addition of $1 \mathrm{~mL}, 1 \mathrm{M} \mathrm{HCl}$. A blank determination on the reagents, in which $5 \mathrm{~mL}$ of $1 \mathrm{M} \mathrm{HCl}$ was poured into $50 \mathrm{~mL}$ standard flask and made up to mark, and the other steps as for the sample were carried out.

Two standard solutions were always prepared alongside each set of absorbance readings; the absorbance due to the blank was always subtracted from that of the sample. The level of aluminum in each sample was obtained by interpolation and the results can be found in Table 1.

\section{Results and Discussion}

The control range concentration of aluminum is $350 \pm$ $130 \mu \mathrm{g} / \mathrm{g}$. The results are within the tolerable limits of aluminium [9, 11-14]. Levels of aluminum in new cooking utensils detected appeared to leach below the control range and extended within the control range. Aluminum detected from the old cooking utensils appeared to leach from below the control range to within the control range. Aluminum detection indicated the possibility of solubility and high concentration of its use by cookware manufacturers.

\section{Conclusion}

Likelihood of leaching occurs mainly in cooking utensils due to factors of temperature and $\mathrm{pH}$, as well as the release of the ions as the years accumulated. Aluminium contamination of the foods tested rice samples from both old and new pots of aluminium, clay, steel, and stainless steel was insufficient to constitute a hazard to health. The fact still remains that once aluminium exceeds the acceptable limit from daily ingestion of food cooked in these pots, coupled with other sources from the environment, diseases such as loss of memory, damage to central nervous system, dementia, severe trembling, and listlessness have adverse effects on health.

\section{References}

[1] A. D. Semwal, A. Padmashree, M. A. Khan, G. K. Sharma, and A. S. Bawa, "Leaching of aluminium from utensils during cooking of food," Journal of the Science of Food and Agriculture, vol. 86, no. 14, pp. 2425-2430, 2006.

[2] M. F. Hassan, M. A. Sadek, F. H. Abd-El-Razik, and E. A. Kamel, "Risk of aluminum toxicity and its relation to some biochemical changes in healthy, diabetic and hyperlepidemic rats," Egyptian Journal of Natural Toxins, vol. 5, no. 1-2, pp. 100-120, 2008.

[3] P. Rajwanshi, V. Singh, M. K. Gupta, and S. Dass, "Leaching of aluminium from cookwares: a review," Environmental Geochemistry and Health, vol. 19, no. 1, pp. 1-18, 1997.

[4] H. J. Gitelman, "Physiology of aluminum in man," in Aluminum and Health, p. 90, CRC Press, 1988.

[5] P. Slanina, W. Frech, and L.-G. Ekstrom, "Dietary citric acid enhances absorption of aluminum in antacids," Clinical Chemistry, vol. 32, no. 3, pp. 539-541, 1986.

[6] M. F. van Ginkel, G. B. van der Voet, P. C. D’Haese, M. E. de Broe, and F. A. de Wolff, "Effect of citric acid and maltol on the accumulation of aluminum in rat brain and bone," Journal of Laboratory and Clinical Medicine, vol. 121, no. 3, pp. 453-460, 1993.

[7] P. Rajwanshi, V. Singh, M. K. Gupta et al., "Studies on aluminium leaching from cookware in tea and coffee and estimation of aluminium content in toothpaste, baking powder and paan masala," Science of the Total Environment, vol. 193, no. 3, pp. 243-249, 1997.

[8] Y. Sakae, K. Shigeo, O. Akihiro, and I. Akira, "Demonstration of aluminum in amyloid fibers in the cores of senile plaques in the brains of patients with Alzheimer's disease," Journal of Inorganic Biochemistry, vol. 103, no. 11, pp. 1579-1584, 2009.

[9] F. S. Mohammad, E. A. H. Al Zubaidy, and G. Bassioni, "Effect of aluminum leaching process of cooking wares on food," International Journal of Electrochemical Science, vol. 6, no. 1, pp. 222-230, 2011.

[10] M. I. S. Veríssimo, J. A. B. P. Oliveira, and M. T. S. R. Gomes, "Leaching of aluminium from cooking pans and food containers," Sensors and Actuators B, vol. 118, no. 1-2, pp. 192-197, 2006.

[11] E. Nagy and K. Jobst, "Aluminium dissolved from kitchen utensils," Bulletin of Environmental Contamination and Toxicology, vol. 52, no. 3, pp. 396-399, 1994. 
[12] H. Habs, B. Simon, and K. U. Thiedemann P, WHO, Aluminium, Environmental Health Criteria 194, IPCS, Aluminium, 1997, http://www.inchem.org/documents/ehc/ehc/ehc194.htm.

[13] E. A. H. Al Zubaidy, F. S. Mohammad, and G. Bassioni, "Effect of $\mathrm{pH}$, salinity and temperature on aluminum cookware leaching during food preparation," International Journal of Electrochemical Science, vol. 6, no. 12, pp. 6424-6441, 2011.

[14] R. Karbouj, I. Desloges, and P. Nortier, "A simple pre-treatment of aluminium cookware to minimize aluminium transfer to food," Food and Chemical Toxicology, vol. 47, no. 3, pp. 571-577, 2009.

[15] K. Tennakone, W. A. C. Perera, and A. C. Jayasuriya, "Aluminium contamination via assisted leaching from metallic aluminium utensils at neutral $\mathrm{pH}$," Environmental Monitoring and Assessment, vol. 21, no. 1, pp. 79-81, 1992.

[16] L. A. Al Juhaiman, "Estimating aluminum leaching from aluminum cookware in different vegetable extracts," International Journal of Electrochemical Science, vol. 7, pp. 7283-7294, 2012. 


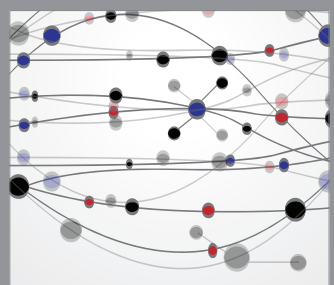

The Scientific World Journal
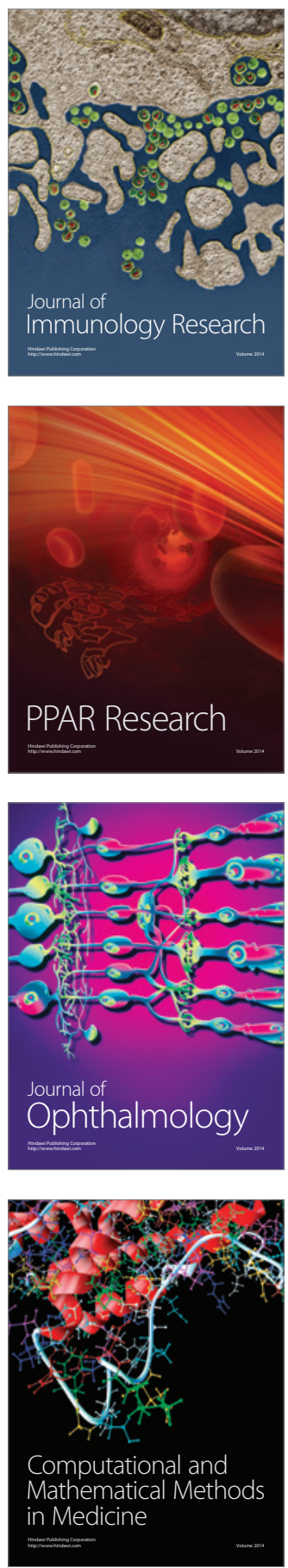

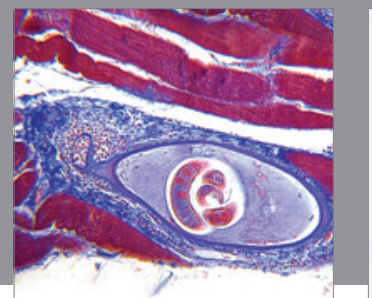

Gastroenterology

Research and Practice
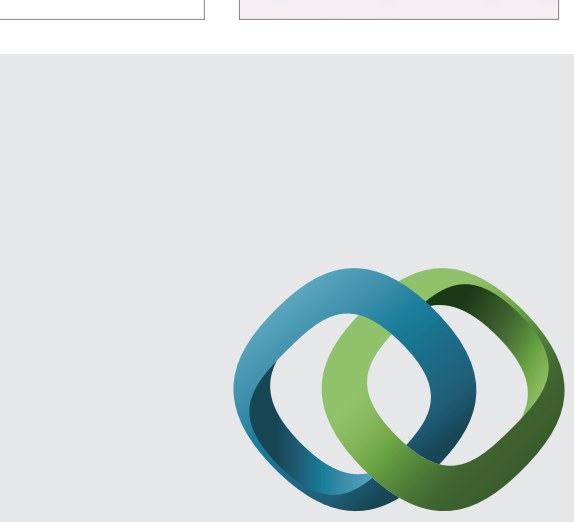

\section{Hindawi}

Submit your manuscripts at

http://www.hindawi.com
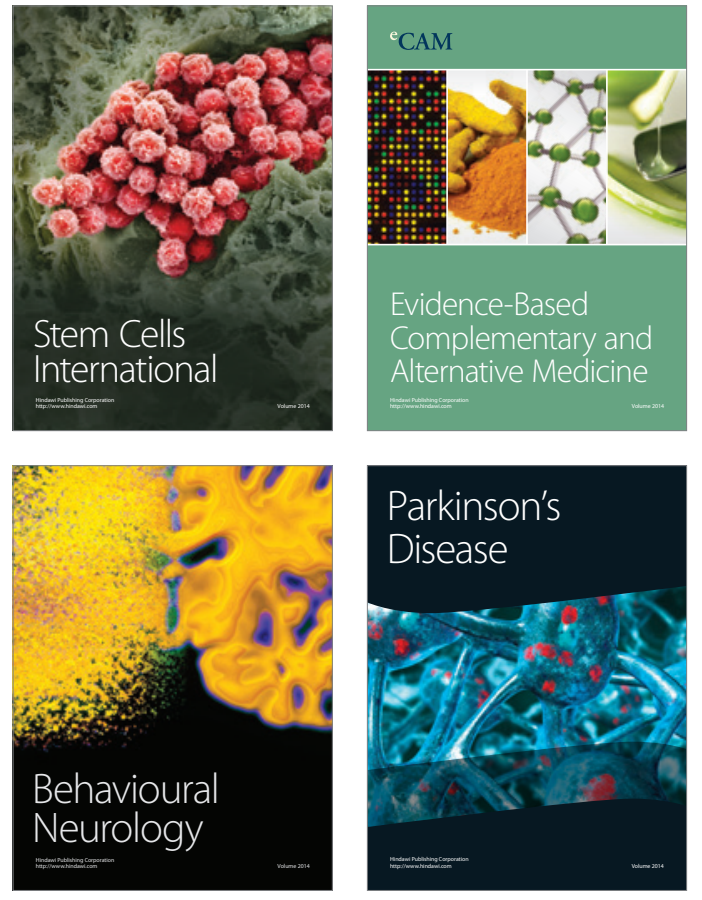
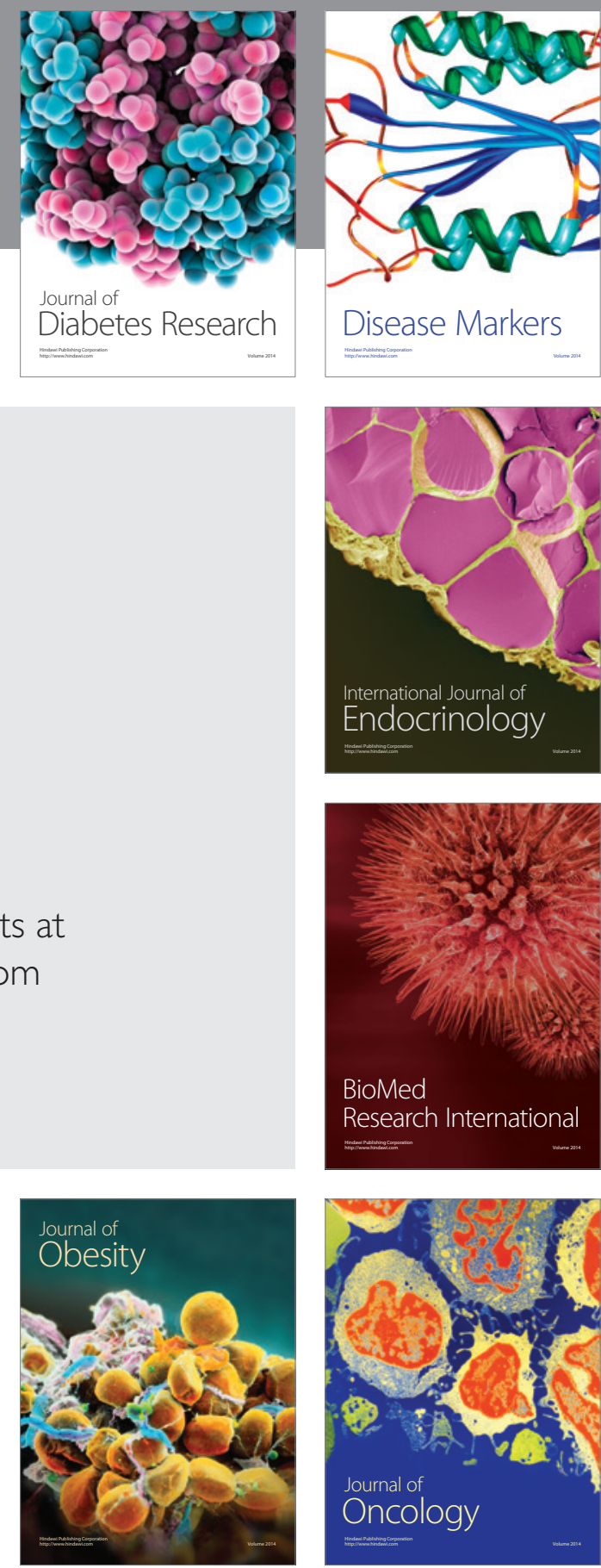

Disease Markers
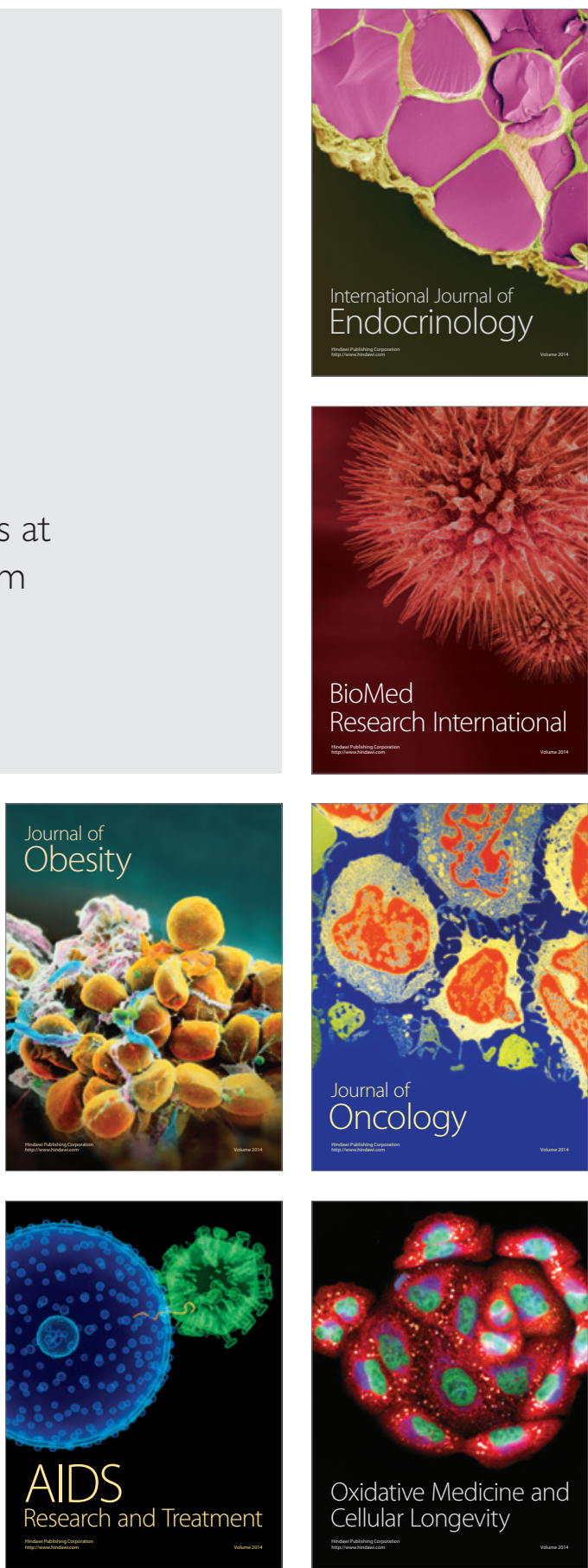